\title{
21. Law, agency and sustainability: the role of law in creating sustainability agency ${ }^{1}$
}

\author{
Jaakko Salminen and Mikko Rajavuori
}

\section{INTRODUCTION}

The concept of 'sustainability agency' is rarely, if at all, used in law or legal scholarship. Yet law provides an essential institutional infrastructure that underpins the actions available to individuals, business organizations, state bureaucracies and international organizations when they seek sustainable outcomes locally or globally. In this chapter, we trace the central role law plays in creating and maintaining the conditions that shape, steer and hamper the emergence of sustainable economic agency in the global economy. We argue that economic agency is deeply immersed in private autonomy and its various legal manifestations, such as the freedom of contract. Autonomy is a privileged legal fundament that structures the decision-making and operation of economic agents and, as an effect, locks in an 'unsustainability agency'. Consequently, disentangling the legal narratives that revolve around sustainability may create significant inroads into how law can be deployed to advance sustainable business and how 'sustainability agency' can inform legal theory.

Our focus is twofold. First, we chart earlier research on the relationship between law and sustainability. To date, research has primarily focused, first, on state-driven regulatory projects that impose public law statutory requirements e.g. for carbon or human rights disclosures, and, second, on private governance initiatives, such as the adoption of voluntary corporate social responsibility codes. The analysis of an increasing penetration of involuntary or voluntary sustainability regulation is expanding in volume and scope and certainly illuminates how changes in allowed, incentivized or prohibited actions affect the overall operation of an economic agent. However, focusing on existing regulatory initiatives fails to explain the behavior prompting the need for such interventions in the first place. Against this backdrop, our second focus rests on the legal root causes undergirding the current system of global production and its severe sustainability deficits, such as excessive carbon emissions and human rights violations. We analyze the constitutive role of law, and private law in particular, in creating, operating and maintaining the dominant unsustainable legal agency conception that has contributed to the rise of externalities of global production both historically and contemporaneously.

Two narratives arise. First, legal interventions seek to make businesses more sustainable. Second, basic legal structures are important drivers in perpetuating unsustainability: While basic legal structural elements, such as contract and corporation, may not in themselves make unsustainability or selfishness a desirable cause of action, they do externalize sustainability by leaving it up to business actors to decide to what extent they focus on profit maximization and to what extent they incorporate considerations of social, environmental, cultural and economic sustainability. To be sure, the dichotomy between these two legal narratives may be less overstated than presented in this chapter. Nonetheless, our key contention is that a better understanding of the interplay of law as a driver of both sustainable and unsustainable 
economic agency provides a better set of tools for recalibrating economic operation towards sustainability in the future. This is particularly so as new forms of organization, such as global value chains and digital platforms, are effective in overriding sustainability regulation designed to counter the unsustainability of earlier modes of organization, such as centralized mass production.

This chapter is organized as follows. In the next section, we provide a critical overview of earlier work on the role of law, expressed mainly through public regulation, in sustainability transitions and more general attempts in steering economic activity towards sustainable outcomes. Due to limited prior discussion on sustainability agency in legal science, the section also develops a working definition of the concept. In the third section, we use the historical development of economic production from nineteenth-century centralized mass production to the platform economy of the twenty-first century to illustrate how private law has incrementally carved out a distinct mode of economic agency bearing on sustainability. Methodologically, the analysis deploys a critical comparison of economic and legal accounts of the history of new forms of industrial organization. In particular, we juxtapose the mainstream literature on the evolution of business, economics and development with a narrative that highlights the relevance of private autonomy and its legal manifestations on the creation of sustainability agency. The fourth section concludes by identifying future research opportunities.

\section{'SUSTAINABILITY' AND 'AGENCY': OVERVIEW OF EARLIER WORK}

\section{The Core Concepts}

While the concept of sustainability agency has seen little, if any, use in legal scholarship, its two constitutive components, 'sustainability' and 'agency', are legal staples. For this reason, any attempt to give meaning to 'sustainability agency' must build on these concepts and interact with their respective research traditions.

In the legal context, 'sustainability' has primarily served as a catch-all category covering a broad range of social, environmental and governance issues that are considered important for various normative projects such as 'civilizing globalization' or 'ecological' sustainability transitions (Lee 2001; Kinley 2009). More recently, however, the uses of 'sustainability' have started to converge to more focused notions based on the economic activity taking place within ecologically relevant planetary boundaries on the one hand and an ideal of socially relevant standards on the other (Sjåfjell and Bruner 2019). The variation in the substantive content notwithstanding, 'sustainability' is increasingly framed as an objective for law to facilitate and achieve (Bosselmann 2016).

'Agency' is also a staple in legal science. Agency law, for example, forms its own distinct area of substantive law that focuses on how actors operate through others, typically separating an agent (who acts) from the principal (the actor for whom the agent acts) (Bennett 2014). While the law-and-economics-influenced theories of 'agency costs' centered on behavioral incentives of various actors in a given sector of law have been the primary touchstone for mainstream legal scholarship (Posner 2014), the notion has also seen use by critical legal scholars. On the one hand, 'agency' is a central concept in a range of critical theories of law, such as feminist theory (Abrams 1995), where it resembles the use of the term in sociology, 
international relations and other social sciences (Giddens 1979; Wight 2006; Hirschmann 2016). On the other hand, the concept of 'agency' has been used as a theoretical base for explaining how law operates and affects its subjects (Parker 2002). Agency has also inspired influential heterodox accounts, often using Bruno Latour's Actor-Network Theory (Latour 2010, 2014) and its subsequent variations exploring the relationship between 'structures' and 'agents' in the operation of regulation more broadly (Riles 2001, 2011).

\section{Law and Changes in Agency}

While it is clear that both 'sustainability' and 'agency' have already emerged as multi-faceted concepts with established legal research traditions, the influence of law for creating and upholding agency relevant for or facilitative of achieving sustainable outcomes has gone undertheorized. Beyond limited theorization on the moral agency of companies (Karp 2014), legal scholarship has generally enacted law as a technique through which existing practices and behavioral patterns that impinge on sustainability can be changed. Rather than engaging with the background conditions that give rise to and motivate particular economic actions, the thrust of existing legal research has focused on regulatory modalities that attempt to change the outer bounds of allowed, incentivized or prohibited behavior.

Historically, altering understandings of how law changes the conduct of regulatory subjects, discerning the legal levers through which this can be achieved and analyzing the impact of the change has been a core task for doctrinal and socio-legal scholarship (Pound 1927; Johnston 1990; Anleu 2009; Friedman 2016). While there certainly are recent examples of adopting an explicit agency perspective on legal change (Viljanen 2016; Rajavuori 2018), it is far more common for any legal examination of 'agency' to turn into a classic inquiry into the conditions, means and impacts of governance: who governs for whom and how and to what effect? Applied to the context of sustainability, a series of detailed questions naturally emerge. Who are the primary drivers of 'sustainability governance' and why (Britton-Purdy et al. 2020)? Should 'sustainability governance', regardless of its source, be operationalized through public regulation or private arrangements (Abbott and Snidal 2009)? And, ultimately, how does 'sustainability governance' affect the rationality of its targets, how is it operationalized in everyday practices and how can we measure its impact (Hickmann 2017; Hsueh 2017)?

These questions are standard fare for studies on regulation, and in the modern context regulators have deployed approaches that build on either hard public law regulation or soft law instruments. Both approaches have a common core: to define the outer bounds of sustainable economic action. Thus, if the issue is the depletion of the ozone layer, regulation seeks to phase out and ultimately end the emissions of the substances causing the depletion. In a global setting, international agreements, such as the Montreal Protocol on Substances that Deplete the Ozone Layer, ${ }^{2}$ are preferable as they guarantee a level playing field beyond the powers of any individual national legislation. If the issue is inadequate data on a company's environmental footprint, regulators devise new reporting obligations that better tackle various sustainability issues, as has been done in the recent amendment to EU's Non-Financial Reporting Directive. ${ }^{3}$ Or if the issue is the involvement of domestic companies in labor violations in faraway jurisdictions with weak legal institutions, the task for law is to incentivize companies to address the deficiencies throughout their supply chains, as the recent wave of transnational sustainability laws indicates (Salminen and Rajavuori 2019). 
In all cases, law - whether international, regional or national, hard or soft - is used instrumentally to adjust the behavior of its targets and, in particular, to internalize the social or environmental externalities of production and economic operation more generally (Cerin and Karlson 2002; Posner 2014). The idea is that certain practices, products and industries would be disincentivized or precluded in a way that is ultimately internalized by the actors themselves. The move towards sustainable outcomes, if any, is seen to flow from altering the regulatory bargains that form the background conditions for economic activity.

Understood this way, the relationship between law and sustainability can be characterized as an incremental expansion of discrete 'sustainability mindsets' - operational frames that mobilize sets of data, indicators and regulatory infrastructures such as reporting obligations (Sarfaty 2013) to incentivize corporate behavior. Much of this earlier literature on law and sustainability has been sector-specific and confined to reactive domains of law, such as specific branches of domestic or international environmental law (Grimeaud 2001; Schneider 2009). Thus, law is seen to function primarily as an adjustment mechanism that deals with the externalities of activities that cause harm, rather than with the underlying causes of these harms themselves.

\section{From Reactive Adjustment Mechanism to Constitution of Economic Agency}

Even when the analysis of the impact of increasing sustainability regulation and private governance initiatives has dominated prior research, in recent years calls for a more comprehensive assessment of 'the laws shaping industrial organization' and their impact on economic action and sustainability have grown more frequent (Viñuales 2018). Instead of focusing on the limited sectoral interventions to distinct sustainability issues, the legal root causes of social and environmental externalities, as well as the likely changes that the most pressing global challenges such as climate change have on law, have been brought to the fore (Biber 2017). In this context, prior research has, again, often emphasized national and international public law or regulation, such as taxation or international trade and investment treaties, as primary factors setting up the parameters that preclude individual agents from pursuing sustainable outcomes (Tienhaara 2018; Bird and Davis-Nozemack 2018; Gammage and Novitz 2019).

By contrast, the foundational role of fundamental private law institutions, such as contract, corporation and property, in creating agency with a particular sustainability mindset has received less attention (Cutler and Dietz 2017; Salminen 2019b; Pistor 2019; Mattei and Quarta 2018; Lang 2013). This lack of focus on the role of private legal institutions muddies the waters even in fields of research beyond law (Deakin et al. 2017; Edelman and Stryker 2005). For example, economics and development studies generally externalize law when focusing on questions such as whether to organize production 'inhouse' or through 'outsourcing' and how to govern production in relation to externalities such as social, environmental, cultural and economic sustainability. Even when the resulting explanations crucially hinge on legal institutions such as corporation and contract, non-legal research generally relies on high-level abstractions of legal concepts (Williamson 1979), with the resulting explanations potentially feeding back into the law with major impact (Britton-Purdy et al. 2020). Furthermore, there is little focus on how the legal parameters of corporation and contract have evolved over time to reflect different societal contingencies (Porta et al. 1998). Our basic private law institutions are taken for granted by not only law but other fields of research — and with them, also the agency created by law. 


\section{THE ROLE OF LAW IN CREATING SUSTAINABILITY AGENCY}

\section{Introduction}

As outlined in the previous section, earlier research on the role of law in shaping economic agency impinging on sustainability has focused primarily on law as an instrument for changing the existing outer bounds of economic activity. This focus, however, leaves aside a more foundational question: what is the role of law in creating agency with particular understandings of how to act in society when pursuing economic action (IGLP Law and Global Production Working Group 2016)? Our contention is that basic private law institutions are often taken for granted in everyday societal interaction, but contracts, corporations and property are nevertheless instrumental in creating and shaping the very agency that most commentators understand law to be merely regulating. The centrality of these institutions becomes evident when they are framed together with the historical development of new forms of organization.

With 'new forms of organization' we refer for example to the rise of centralized mass production in the nineteenth century, its fragmentation into global value chains in the twentieth century, and the further fragmentation of global value chains via the platform economy in the twenty-first century. While ostensibly grounded in the invention of new technologies and ideologies of governance, the development of each of these modes of organization is intricately linked to legal innovation. When the technological and ideological narratives of economic development are transposed with their undergirding legal operability, the role of law in providing tools, background conditions and particular approaches — agencies — for the actors that drive economic activity becomes clear.

\section{Law and the Rise of Economic Agency: A Historical View}

Consider the influential account of Richard Baldwin, who argues that centralized mass production only became feasible when production could be effectively separated from consumption (Baldwin and Martin 1999; Baldwin 2011, 2019). During the nineteenth century, the rise of new transport technologies, such as railroads and steamships, enabled the global distribution of goods. Global distribution, in turn, broke down earlier limits on how much production could be amassed in one physical space. This, coupled with the comparatively efficient bureaucratic control of centralized entities, enabled ever greater economies of scale, resulting in the rise of centralized mass production entities and global distribution chains.

These developments in technologies and business practices coincided with a rise of new private law paradigms. Most importantly, these new 'legal technologies' pivoted on the expanding reach of private autonomy and the freedom of a particular kind of rational actor-one that engages in rational-purposeful action (Weber 1978 [1921]) — to enter into commitments with one another (Atiyah 1979; Bainbridge and Henderson 2018). The liberal conception of autonomy embedded in the basic structures of private law essentially enacted the producers as actors that did not need to consider the interests of consumers, labor or the environment. Law merely set these actors free to pursue their own narrowly defined interests, such as turning a profit, within the limits of lawfulness. What was not prohibited, was allowed. Coupled with the bankruptcy protections provided to the limited liability corporate form, contracts, property and the binary mentality of law allowed the new production entities to separate 'externalities', such as relationships to consumers, labor and the environment, from 
production (Stapleton 1994; Bernstein 2005; Bainbridge and Henderson 2018; Lis 2012; Peel and Osofsky 2015).

A decision by the US Supreme Court, Lochner v. New York, is often used to illustrate the power of private autonomy (Bernstein 2005). In the case, the court ruled that a state law limiting bakery worker hours to under ten hours a day amounted to 'unreasonable, unnecessary and arbitrary interference with the right and liberty of the individual to contract'. ${ }^{4}$ Ultimately, any such radical laissez-faire approach to freedom of contract gradually dissolved in the face of acute societal conflicts. Regulation expanded to govern social and environmental externalities through e.g. local labor, consumer and environmental regulation (Atiyah 1979). However, the underlying core private law structures that had enabled the laissez-faire approach in the first place were not directly affected, even though the development of e.g. product liability law arguably came close to eliciting more radical change (Stapleton 1994).

A similar development, whereby existing legal structure allows a new form of organization to arise and law then scrambles to alleviate ensuing social, environmental and economic externalities ex post, took place in the twentieth century in relation to the rise of global value chains. Following Baldwin's account, new communication technologies enabled the control of production from afar (Baldwin 2019). Significant changes in business practices ensued: Smaller and more nimble actors focusing on their 'core competences' were seen as more efficient than vertically integrated large corporations trying to gather all aspects of business under one roof (Prahalad and Hamel 1990). As a result, the earlier ideal mode of organization, centralized mass production, fragmented within and across jurisdictional boundaries as production chains consisting of multiple specialized production entities emerged. While seemingly independent, these fragmented entities needed to be coordinated in order to secure production and to ensure value-chain-wide logistics cost-efficiency, research and development, compliance with target market product standards and, eventually, ethical and sustainability requirements. Thus, value chain governance by lead firms, by using measures ranging from codes of conduct to specialized governance agreements, became the necessary glue uniting and coordinating geographically and organizationally fragmented production networks (Gereffi, Humphrey, and Sturgeon 2005; Locke 2013; Salminen 2020).

While clearly a new form of economic organization in contrast to centralized mass production, the rise of global value chains was built on the same private law concepts of contract and corporation that had also enabled its predecessor. The adoption of the notion that corporations could own controlling equity stakes in other corporations quickly transnationalized corporate groups while the veils created by separate legal personality shielded the assets of individual corporations from failures of associated entities (Muchlinski 2010). Contracts signed with local and foreign suppliers provided the legal infrastructure for an even more massive fragmentation of production (Muchlinski 2013). Even though the social and environmental problems of centralized mass production had, to a degree, been countered with local regulations focusing on the on-shore entities, the geographical and organizational fragmentation of production evaded these regulations and thus highlighted the persistence of the underlying laissez-faire approach of private autonomy embedded in contract and corporation. Earlier labor regulations and collective agreements targeting centralized production entities, for example, would not automatically extend to aspects of production that were contractually outsourced to other kinds of entities (Weil 2014), not to mention globally (Hepple 2005). When applied to a transnational setting, the concepts of contract and corporation thus enabled companies to benefit from regu- 
latory arbitrage and avoid liability for externalities caused by the new standard of outsourced and off-shored production (Zumbansen 2013).

Similarly to centralized mass production, the sustainability deficit ensuing from global value chains has elicited increasingly focused responses through developments in regulation, legal doctrine and private governance arrangements. Legislators are currently experimenting with regulation targeting the externalities of transnational production (Bueno and Bright 2020; Salminen and Rajavuori 2019), courts are developing new doctrines related to limited liability and contractual boundaries (Salminen 2019a; Terwindt, Leader, and Yilmaz-vastardis 2017) and companies are deploying new governance mechanisms to govern sustainability on a value-chain-wide scale (Dadush 2019; Salminen 2018). Despite such developments, however, it seems that the crux of the contemporary legal infrastructure, the core structures of private law, still evades major changes (Pistor 2019). This is particularly visible in forthcoming developments related to global production.

According to Baldwin's narrative, the digitalization and the rise of algorithmic actors will further fracture value chains (Baldwin 2019). Until the early twenty-first century, buyer- or producer-driven lead firms were seen as the primary actors driving value chain governance (Gereffi 2001). The development of digital platforms, however, enables a second wave of fragmentation by outsourcing value chain governance to platform operators. This, in a sense, democratizes both business governance and work on an unprecedented scale, at least to those able to participate in the platform economy. First, not only corporations of all sizes but also private individuals can design the goods or services they need and outsource the production of these goods globally. ${ }^{5}$ Second, with the help of advanced algorithms and telepresence technology, not only corporations but also individuals can outsource their services globally, whether they are outsourcing manual labor or their white-collar expertise as designers, engineers or lawyers consulting people around the globe online, pilots operating drones over distant skies, manufacturers of specialty components with 3D printers, or doctors or surgeons consulting and operating patients on other continents.

The second wave of fragmentation exacerbates current transnational regulatory voids and leads existing sustainability regulation, aimed at either local production or locally governed but globally projected value chains, to lose whatever traction it may have. As platform operators are not directly party to the agreements between buyers and sellers, without new regulatory interventions operators may escape liability for externalities spurred by such transactions (Domurath 2018). While there are inklings of locally or regionally embedded platform operator regulation in sectors such as gig-work (Cauffman 2019), these initiatives can typically be overridden by platform operators located in jurisdictions other than those of their users (Busch 2019). New regulatory devices, such as sustainability indicators for digital platforms, will no doubt be able to counter some of the externalities of platform economies (Sankari 2019). At the same time, because the private law institutions that underpin new forms of organization remain unchanged, yet again new forms of ex post regulatory intervention will be necessary to counter the externalities unleashed by digital platforms.

For just one example, if platforms enable private individuals to take the place of traditional lead firms in value chains, one of the coming waves of sustainability regulation would have to focus not on companies but on private individuals, such as consumers, as the only locally embedded operators of transnational platforms and thus as the only actors within the reach of traditional, domestic regulation. ${ }^{6}$ To date, consumers have generally been seen as actors whose freedom to act should be protected even when this freedom might lead to unsustainable 
choices, but this view has received increasing criticism with the realization that consumers can become a major driver of unsustainable production (Tjon Soei Len 2020). It remains to be seen if novel regulatory instruments, such as automatic customs and taxation schemes on private consumer shipments purchased through transnational digital platforms, will prompt change in the consumer sustainability mindset. ${ }^{7}$

\section{How Law Creates Economic Agency (and Why it Matters for Sustainability)?}

In sum, the history of economic organization over the past two centuries illustrates the central role of law in the emergence of its background conditions and new developmental forms. More crucially, however, the historical backdrop also provides a view into the dynamics through which private law and public regulation together shape the agency of economic action. Ever since the rise of the liberal paradigm, the core private law institutions have served to enable, if not encourage, the pursuit of callous wealth maximization strategies that push the externalities of social, environmental, cultural and economic unsustainability to other actors, such as individuals, communities, the state and the global ecosystem. As the historical exposition of the new forms of production sought to illustrate, the ensuing 'unsustainability agency' enacted and performed by private law institutions has not been effectively contested to date. Instead, each new form of production is from the onset mostly blind to economic, social and environmental externalities unless externally regulated. Freedom is the default position in private law, and the scope of the freedom includes unsustainable actions.

The mechanics of unsustainability, though legal, do not arise out of explicit decisions by legislators or other formal legal processes. Instead, the default unsustainability emerges from legal innovations that deploy the liberal core institutions of private law. Each historical shift in the dominant mode of organization, be it the rise of centralized mass production in the nineteenth century, global value chains in the twentieth century or the platform economy in the twenty-first century, is undergirded by legal innovations. In all cases, legal innovations have incrementally expanded the scope of private autonomy through nigh immutable concepts such as 'freedom of contract' or 'limited liability'. Legislators, courts and other legal actors play a game of catch-up, seeking to rein in the economic, social and environmental externalities flowing from the strategic experimentation with the limits of contract and corporation locally or globally. It is through this cumulative process of innovations and reactions that law creates economic agency, a particular mentality that defines what different actors, such as corporations and consumers, are intrinsically interested in. Regulation defines a baseline of lawfulness, allowing the actors to display a (dis)interest in social, environmental, cultural, or economic sustainability beyond the black letter requirements. Whether the actors choose to act sustainably is their choice. What is clear, however, is that, in order to effectively talk about sustainability and its regulation, we must acknowledge the role of the underlying paradigms of law in creating our current sustainability agency.

\section{CONCLUSION: THE FUTURE OF LAW AND SUSTAINABILITY AGENCY}

This chapter has analyzed the legal creation of economic agency and its impact on sustainability. While significant, the role of law in crafting and structuring particular behavioral modes 
of economic operation is necessarily embedded in a broader matrix of technological and ideological development. By tracing the existing patterns of legal research on sustainability regulation and governance and providing a counternarrative based on the historical development of private law, we have illustrated the dynamics of the law-created economic agency.

Our contention, in sum, is that the basic private law paradigms of corporation and contract have historically evolved to exclude sustainability considerations, thus creating a very specific kind of economic agency which, from a contemporary perspective, could be summarized as 'unsustainability agency'. While several external regulatory actions have tried to rein in the sustainability deficits of economic operation in different eras, the incremental expansion of private autonomy and rational wealth maximization continue to reproduce economic, social and environmental externalities across geographical and organizational boundaries. Even though the development of public or private sustainability regulation and governance may reduce the most acute ills of the global value chain or platform capitalism, the crux of the issue remains.

In order to go beyond the currently dominant modes of economic agency, we suggest, law needs to go beyond its function as an adjustment mechanism and focus on the legal root causes that underlie the constitution of the 'unsustainability agency' and its ensuing real-world externalities. Moreover, a closer legal analysis of sustainability agency opens numerous pathways for further cross-disciplinary research. Business and economic historians, for instance, may use the 'silent history' of private law to weave more nuanced narratives of economic globalization, whereas economic geographers and political economists may rely on it to analyze institutional underpinnings and power structures of current corporate imperialism. For management scholars, the dynamics of private governance and the constant evolution of private autonomy provide novel analytical tenets that can be used as a springboard to theorize the opportunities and limits of corporate social responsibility initiatives. Similarly, scholars of sustainability science may be better able to locate the most effective leverage points for pushing progressive sustainability policies either on states or companies. In all of this, however, the job for legal professionals - legislators, courts, corporate counsel and legal scholars - is to try and re-imagine the basic tenets of private law, as is already being done in relation to foundational concepts such as the purpose of the corporation (Sjåfjell 2018) or the privity of contracts (Eller and Salminen 2020), or even to re-imagine law more generally (Kjaer 2020).

\section{ACKNOWLEDGMENTS}

We would like thank Mika Viljanen for his extensive comments on an earlier version of this chapter. We acknowledge the support of the Academy of Finland through the projects The Law of the Green Developmental State: State Shareholders in Climate Governance (grant no. 324037) and Law for Secure Supply: Internalizing the Crisis Exceptions ('LEXSECURE', grant nos. 338643 and 338645).

\section{NOTES}

1. This is an open access work distributed under the Creative Commons Attribution-NoDerivatives 4.0 International (CC BY-ND 4.0). Users can redistribute the work for non-commercial purposes, as long as it is passed along unchanged and in whole, as detailed in the License. Edward Elgar 
Publishing Ltd must be clearly credited as the rights holder for publication of the original work. Any translation or adaptation of the original content requires the written authorization of Edward Elgar Publishing Ltd.

2. Montreal Protocol on Substances that Deplete the Ozone Layer, September 16, 1987, T.I.A.S. No. 11,097, 1522 U.N.T.S. 3.

3. European Commission, 'Guidelines on non-financial reporting: Supplement on reporting climate-related information' (2019/C 209/01).

4. Joseph Lochner, Plaintiff in Error v. People of the State of New York (1905). 198 U.S. 45.

5. For example through platforms such as SupplyCompass (supplycompass.com) or Alibaba (alibaba.com).

6. For one recent example of what the unregulated behavior of individuals can lead to on platforms, see Jack Nicas, 'He Has 17.700 Bottles of Hand Sanitizer and Nowhere to Sell Them', New York Times March 14, 2020, available at https://www.nytimes.com/2020/03/14/technology/coronavirus-purell -wipes-amazon-sellers.html_(accessed September 1, 2020).

7. One example is provided by the Swedish initiative of automatically taxing all shipments arriving from outside the European Union, which, together with administrative fees, considerably increases the price of low value shipments. See Stefan Hesserud Persson, '11 frågor om Postnords avgift på Kinapaket', Aftonbladet July 1, 2019, available at https://www.aftonbladet.se/minekonomi/a/ gPOj59/11-fragor-om-postnords-avgift-pa-kinapaket (accessed September 1, 2020).

\section{REFERENCES}

Abbott, Kenneth W. and Duncan Snidal (2009), 'Strengthening International Regulation Through Transnational New Governance: Overcoming the Orchestration Deficit', Vanderbilt Journal of Transnational Law 42 (2), 501-578.

Abrams, Kathryn (1995), 'Sex Wars Redux: Agency and Coercion in Feminist Legal Theory', Columbia Law Review 95 (2), 304-376.

Anleu, Sharyn L. Roach (2009), Law and Social Change, London: Sage.

Atiyah, Patrick S. (1979), The Rise and Fall of Freedom of Contract, Oxford: Oxford University Press.

Bainbridge, Stephen M. and M. Todd Henderson (2018), Limited Liability: A Legal and Economic Analysis, Cheltenham, UK and Northampton, MA, USA, Edward Elgar Publishing.

Baldwin, Richard (2011), 'Trade and Industrialization after Globalization's 2nd Unbundling: How Building and Joining a Supply Chain Are Different and Why It Matters', NBER Working Paper Series 17716 .

Baldwin, Richard (2019), The Globotics Upheaval: Globalization, Robotics, and the Future of Work, Oxford: Oxford University Press.

Baldwin, Richard and Philippe Martin (1999), 'Two Waves of Globalization: Superficial Similarities, Fundamental Differences', NBER Working Paper Series 6904.

Bennett, Howard (2014), Principles of the Law of Agency, London: Bloomsbury Publishing.

Bernstein, David (2005), 'Lochner v. New York: A Centennial Retrospective', Washington University Law Quarterly 85 (5), 1469-1528.

Biber, Eric (2017), 'Law in the Anthropocene Epoch', Georgetown Law Journal 106 (1), 1-68.

Bird, Robert and Karie Davis-Nozemack (2018), 'Tax Avoidance as a Sustainability Problem', Journal of Business Ethics 151 (4), 1009-1025.

Bosselmann, Klaus (2016), The Principle of Sustainability: Transforming Law and Governance, Abingdon: Routledge.

Britton-Purdy, Jedediah, David Singh Grewal, Amy Kapczynski and K. Sabeel Rahman (2020), 'Building a Law-and-Political-Economy Framework: Beyond the Twentieth-Century Synthesis', Yale Law Journal 129 (6), 1784-1835.

Bueno, Nicolas and Claire Bright (2020), 'Implementing Human Rights Due Diligence Through Corporate Civil Liability', International and Comparative Law Quarterly 69 (4), 789-818.

Busch, Christoph (2019), 'When Product Liability Meets the Platform Economy: A European Perspective on Oberdorf v. Amazon', Journal of European Consumer and Market Law 8 (5), 173-174. 
Cauffman, Caroline (2019), 'New EU Rules on Business-to-Consumer and Platform-to-Business Relationships', Maastricht Journal of European and Comparative Law 26 (4), 469-479.

Cerin, Pontus and Lennart Karlson (2002), 'Business Incentives for Sustainability: A Property Rights Approach', Ecological Economics 40 (1), 13-22.

Cutler, A. Claire and Thomas Dietz (2017), 'The Politics of Private Transnational Governance by Contract: Introduction and Analytical Framework', The Politics of Private Transnational Governance by Contract, London: Routledge, 1-36.

Dadush, Sarah (2019), 'Contracting for Human Rights: Looking to Version 2.0 of the ABA Model Contract Clauses', American University Law Review 68 (1), 1519-1554.

Deakin, Simon, David Gindis, Geoffrey M. Hodgson, Kainan Huang and Katharina Pistor (2017), 'Legal Institutionalism: Capitalism and the Constitutive Role of Law', Journal of Comparative Economics 45 (1), 188-200.

Domurath, Irina (2018), 'Platforms as Contract Partners: Uber and Beyond', Maastricht Journal of European and Comparative Law 25 (5), 565-581.

Edelman, Lauren B. and Robin Stryker (2005), 'A Sociological Approach to Law and the Economy', Neil J. Smelser and Richard Swedberg (eds), The Handbook of Economic Sociology, 2nd ed., Princeton, NJ: Princeton University Press, 527-551.

Eller, Klaas Hendrik and Jaakko Salminen (2020), 'Reimagining Contract in a World of Global Value Chains', European Review of Contract Law 16 (1), 1-2.

Friedman, Lawrence M. (2016), Impact: How Law Affects Behavior, Cambridge, MA: Harvard University Press.

Gammage, Clair and Tonia Novitz (2019), ‘Trade, Investment and Corporate Sustainability', Beate Sjåfjell and Christopher M. Bruner (eds), The Cambridge Handbook of Corporate Law, Corporate Governance and Sustainability, Cambridge: Cambridge University Press, 15-28.

Gereffi, Gary (2001), 'Shifting Governance Structures in Global Commodity Chains, With Special Reference to the Internet', American Behavioral Scientist 44 (10), 1616-1637.

Gereffi, Gary, John Humphrey and Timothy Sturgeon (2005), 'The Governance of Global Value Chains', Review of International Political Economy 12 (1), 78-104.

Giddens, Anthony (1979), 'Central Problems in Social Theory. Action, Structure and Contradiction in Social Analysis', Central Problems in Social Theory, Basingstoke, UK: Palgrave Macmillan, 49-95.

Grimeaud, David (2001), 'Reforming EU Water Law: Towards Sustainability?', European Energy and Environmental Law Review 10 (4), 125-134.

Hepple, Bob (2005), Labour Laws and Global Trade, London: Hart Publishing.

Hickmann, Thomas (2017), 'Voluntary Global Business Initiatives and the International Climate Negotiations: A Case Study of the Greenhouse Gas Protocol', Journal of Cleaner Production 169, 94-104.

Hirschmann, Nancy J. (2016), 'Freedom, Power and Agency in Feminist Legal Theory', Vanessa E. Munro and Margaret Davies (eds), The Ashgate Research Companion to Feminist Legal Theory, Abingdon, UK: Routledge, 63-76.

Hsueh, Lily (2017), 'Transnational Climate Governance and the Global 500: Examining Private Actor Participation by Firm-Level Factors and Dynamics', International Interactions 43 (1), 48-75.

IGLP Law and Global Production Working Group (2016), 'The Role of Law in Global Value Chains: A Research Manifesto', London Review of International Law 4 (1), 57-79.

Johnston, Jason Scott (1990), 'Review Essay: Law, Economics, and Post-Realist Explanation', Law \& Society Review 24 (5), 1217-1254.

Karp, David Jason (2014), Responsibility for Human Rights: Transnational Corporations in Imperfect States, Cambridge: Cambridge University Press.

Kinley, David (2009), Civilising Globalisation, Cambridge: Cambridge University Press.

Kjaer, Poul F. (2020), 'The Law of Political Economy', The Law of Political Economy: Transformation in the Function of Law, Cambridge: Cambridge University Press, 1-30.

Lang, Andrew T. F. (2013), 'The Legal Construction of Economic Rationalities?', Journal of Law and Society 40 (1), 155-171.

Latour, Bruno (2010), The Making of Law: An Ethnography of the Conseil d'Etat, Cambridge: Polity.

Latour, Bruno (2014), 'Agency at the Time of the Anthropocene', New Literary History 45 (1), 1-18. 
Lee, Kai N. (2001), 'Searching for Sustainability in the New Century', Ecology Law Quarterly 27, 913-928.

Lis, Kamila (2012), 'Coalitions in the Jungle: Advancing Animal Welfare through Challenges to Concentration in the Meat Industry', Animal Law Review 19 (1), 63-89.

Locke, Richard M. (2013), The Promise and Limits of Private Power: Promoting Labor Standards in a Global Economy, Cambridge: Cambridge University Press.

Mattei, Ugo and Alessandra Quarta (2018), The Turning Point in Private Law: Ecology, Technology and the Commons, Cheltenham, UK and Northampton, MA, USA, Edward Elgar Publishing.

Muchlinski, Peter (2010), 'Limited Liability and Multinational Enterprises: A Case for Reform?', Cambridge Journal of Economics 34 (5), 915-28.

Muchlinski, Peter (2013), 'The Development of German Corporate Law Until 1990: An Historical Reappraisal', German Law Journal 14 (2), 339-79.

Parker, Christine (2002), The Open Corporation: Effective Self-Regulation and Democracy, Cambridge: Cambridge University Press.

Peel, Jacqueline and Hari M. Osofsky (2015), Climate Change Litigation, Cambridge: Cambridge University Press.

Pistor, Katharina (2019), The Code of Capital: How the Law Creates Wealth and Inequality, Princeton, NJ: Princeton University Press.

Porta, Rafael La, Florencio Lopez-de-Silanes, Andrei Shleifer and Robert W. Vishny (1998), 'Law and Finance', Journal of Political Economy 106 (6), 1113-1155.

Posner, Richard A. (2014), Economic Analysis of Law, Alphen aan den Rijn, Netherlands: Wolters Kluwer.

Pound, Roscoe (1927), 'Law and Social Work', Indiana Law Journal 3 (3), 183-195.

Prahalad, Coimbatore Krishnarao and Gary Hamel (1990), 'The Core Competence of the Corporation', Harvard Business Review 68 (3), 79-91.

Rajavuori, Mikko (2018), 'Governing the Good State Shareholder: The Case of the OECD Guidelines on Corporate Governance of State-Owned Enterprises', European Business Law Review 29 (1), 103-42.

Riles, Annelise (2001), The Network Inside Out, Ann Arbor, MI: University of Michigan Press.

Riles, Annelise (2011), Collateral Knowledge: Legal Reasoning in the Global Financial Markets, Chicago, IL: University of Chicago Press.

Salminen, Jaakko (2018), 'The Accord on Fire and Building Safety in Bangladesh-A New Paradigm for Limiting Buyers' Liability in Global Supply Chains?', American Journal of Comparative Law 66 (2), 411-451.

Salminen, Jaakko (2019a), 'From Product Liability to Production Liability: Modelling a Response to the Liability Deficit of Global Value Chains on Historical Transformations of Production', Competition \& Change 23 (4), 420-438.

Salminen, Jaakko (2019b), 'Sustainability and the Move from Corporate Governance to Governance Through Contract', Beate Sjåfjell and Christopher Bruner (eds), Cambridge Handbook of Corporate Law, Corporate Governance and Sustainability, Cambridge: Cambridge University Press, 57-70.

Salminen, Jaakko (2020), 'Towards a Genealogy and Typology of Governance Through Contract Beyond Privity', European Review of Contract Law 16 (1), 25-43.

Salminen, Jaakko and Mikko Rajavuori (2019), 'Transnational Sustainability Laws and the Regulation of Global Value Chains: Comparison and a Framework for Analysis', Maastricht Journal of European and Comparative Law 26 (5), 1-26.

Sankari, Suvi (2019), 'Product Information on Freight Emissions for Consumers - Changing the Market towards Sustainability', Ellen Eftestöl-Wilhelmsson, Anu Bask, Suvi Sankari (eds), Sustainable and Efficient Transport: Incentives for Promoting a Green Transport Market, Cheltenham, UK and Northampton, MA, USA, Edward Elgar Publishing, 212-228.

Sarfaty, Galit (2013), 'Regulating Through Numbers: A Case Study of Corporate Sustainability Reporting', Virginia Journal of International Law 53 (3), 575-621.

Schneider, Susan A. (2009), 'A Reconsideration of Agricultural Law: A Call for the Law of Food, Farming, and Sustainability', William \& Mary Environmental Law \& Policy Review 34, 935-963.

Sjåfjell, Beate (2018), 'Redefining the Corporation for a Sustainable New Economy', Journal of Law and Society 45, 29-45. 


\section{Research handbook of sustainability agency}

Sjåfjell, Beate and Christopher M. Bruner (2019), 'Corporations and Sustainability', The Cambridge Handbook of Corporate Law, Corporate Governance and Sustainability, Cambridge: Cambridge University Press, 3-12.

Stapleton, Jane (1994), Product Liability, Oxford: Butterworth.

Terwindt, Carolijn, Sheldon Leader and Anil Yilmaz-vastardis (2017), 'Supply Chain Liability: Pushing the Boundaries of the Common Law?', Journal of European Tort Law 8 (3), 261-296.

Tienhaara, Kyla (2018), 'Regulatory Chill in a Warming World: The Threat to Climate Policy Posed by Investor-State Dispute Settlement', Transnational Environmental Law 7 (2), 229-50.

Tjon Soei Len, Lyn K.L. (2020), 'Hermeneutical Injustice, Contract Law, and Global Value Chains', European Review of Contract Law 16 (1), 138-158.

Viljanen, Mika (2016), 'Making Banks on a Global Scale: Management-Based Regulation as Agencement', Indiana Journal of Global Legal Studies 23 (2), 425-453.

Viñuales, Jorge E. (2018), 'The Organisation of the Anthropocene: In Our Hands', International Legal Theory and Practice 1 (1), 1-81.

Weber, Max (1978 [1921]), Economy and Society, G. Roth and C. Wittich (eds), Berkeley, CA: University of California Press.

Weil, David (2014), The Fissured Workplace: Why Work Became So Bad for So Many and What Can Be Done to Improve It, Cambridge, MA: Harvard University Press.

Wight, Colin (2006), Agents, Structures and International Relations: Politics as Ontology, Cambridge: Cambridge University Press.

Williamson, Oliver (1979), 'Transaction-Cost Economics: The Governance of Contractual Relations', Journal of Law \& Economics 22 (2), 233-261.

Zumbansen, Peer (2013), 'Lochner Disembedded: The Anxieties of Law in a Global Context', Indiana Journal of Global Legal Studies 20 (1), 29-69. 